DOI

\title{
СТАН ІМУННОГО ГОМЕОСТАЗУ ПРИ ПОРУШЕННІ МЕНСТРУАЛЬНОГО ЦИКЛУ У ЖІНОК, ЩО ХВОРІЮТЬ НА ТУБЕРКУЛЬОЗ
}

\author{
๑о. В. Романюк, С. П. Польова
}

Ковельський медичний коледж

\begin{abstract}
РЕЗЮМЕ. Наведені дані досліджень показників імунного протиінфекційного захисту у пацієнток із порушеннями менструального циклу (ПМЦ), які хворіють на туберкульоз (ТБ) легень. Показано, що в результаті змін неспецифічної ефекторної системи протиінфекційного захисту та клітинної ланки системи імунітету на тлі туберкульозу менструальний цикл (МЦ) у даної когорти жінок зазнає суттєвих порушень. Встановлено, що у пацієнток, хворих на ТБ легень, формується набутий імунодефіцитний стан за клітинним типом. Встановлена роль гуморальної ланки системного імунітету у комплексі порушень менструальної функції пацієнток, які хворіють на туберкульоз.
\end{abstract}

КЛЮчОВІ СлОВА: туберкульоз, менструальний цикл, імунна система, діагностика.

Вступ. За наявності туберкульозу легень у жінок репродуктивного віку наявні різноманітні порушення менструальної функції (72,3\%) з переважанням дисменореї та менорагії, частка яких при розповсюджених і поєднаних формах ТБ удвічі вища, порівняно з вогнищевим ураженням легеневої тканини $[3,4,8]$. ПМЦ трапляються у $36,8 \%$ жінок, хворих на ТБ, при цьому альгодисменорея має місце у 30,0 \%, гіперполіменорея - у $26,8 \%$, схильність до проліферативних змін ендометрія з переважанням залозистої гіперплазії - у 28,9 \%, кісти і новоутворення яєчників -у 24,7\%, первинна та вторинна аменорея -у 8,1 \% випадків тощо. Кожна третя пацієнтка, хвора на ТБ легень, вказує на встановлення менструації у віці старше 14 років $[2,6,7]$.

Основним механізмом захисту організму за умов туберкульозу $\epsilon$ Т-клітинна ланка імунної системи, яка формує протитуберкульозний імунітет, здійснює регуляцію фагоцитозу і лізису МБТ і тому заслуговує на поглиблене вивчення з точки зору впливу на менструальний цикл, репродуктивні органи, гормональну та ендокринну системи та реактивність організму загалом у пацієнток, які хворіють на туберкульоз легень $[1,4,5,9,10]$. Суттєву роль відіграє і гуморальна ланка імунітету, зважаючи, що антитіла до антигенів МБТ циркулюють у крові за наявності будь-якої форми ТБ, а імунна відповідь складна і залежить від багатьох чинників $[2,4,9]$.

Мета. Визначити показники неспецифічного та специфічного імунного протиінфекційного захисту у жінок з ПМЦ, які хворіють на туберкульоз легень.

Матеріал і методи дослідження. Проведено обстеження 48 пацієнток репродуктивного віку, хворих на ТБ легень (основна група), та 30 здорових жінок (контрольна група).

Цільну кров досліджували на гематологічному аналізаторі «Celtrak-11» фірми «Ваег»
(Австрія). Фагоцитарну активність нейтрофілів крові досліджували у фагоцитарній реакції за визначенням фагоцитарного числа та фагоцитарної активності у відсотках фагоцитуючих клітин. Основні субпопуляції Т- і В-лімфоцитів визначали у реакції непрямої поверхневої імунофлуоресценції з моноклональними антитілами (фірми «Сорбент-лтД", Москва).

Результати й обговорення. Результати досліджень показали, що із 48 пацієнток основної групи 26 (54,1 \%) хворіли на вперше діагностований дисемінований туберкульоз, 18 (37,5 \%) - на фіброзно-кавернозний і 4 (8,3\%) - на вогнищевий. Порушення менструальної функції спостерігали у $34(70,8 \%)$ жінок, хворих на туберкульоз легень. Комплексна оцінка даних анамнезу показала, що у 21 (43,7 \%) пацієнтки мало місце пізнє менархе. Функціональні порушення репродуктивної функції проявлялися альгодисменореєю-у 16 (33,0\%), дисменореєю - у 11 (22,9\%), гіперполіменореєю і опсоменореєю - у $9(18,7 \%)$, аменореєю - у $3(6,2 \%)$ oci6.

У пацієнток основної групи виявлені суттєві зміни показників неспецифічної ефекторної системи протиінфекційного захисту, при цьому III ступінь імунних порушень виявлено у $50 \%$ жінок основної групи, II - у $37 \%$, i I-у $12,5 \%$ осіб.

Наявність вперше діагностованого ТБ легень у жінок репродуктивного віку призвела до суттєвих порушень механізмів неспецифічного протиінфекційного захисту: фагоцитарна активність лейкоцитів у пацієнток основної групи знижувалася на $16,4 \%$, їх бактерицидна активність зростала на 57,9 \% (табл. 1). Потенційна здатність до бактерицидної активності фагоцитів знижувалася на 40,0 \%, показник фагоцитарного резерву знижувався у 3,42 раза, що призводило до незавершеності фагоцитозу. При цьому імунологічний коефіцієнт зростав на 85,9 \%, про що засвідчили ПМЦ, які перебігають на тлі інфекційного процесу. 
Огляди літератури, оригінальні дослідження, погляд на проблему

Таблиця 1. Показники неспецифічної системи протиінфекційного захисту у жінок, які хворіють на туберкульоз легень

\begin{tabular}{|c|c|c|c|c|c|c|}
\hline \multirow[b]{2}{*}{ Показники } & \multirow[b]{2}{*}{$\begin{array}{c}\text { Одиниці } \\
\text { вимірювання }\end{array}$} & \multicolumn{4}{|c|}{ Групи обстежуваних жінок } & \multirow[b]{2}{*}{$P$} \\
\hline & & $\begin{array}{c}\text { основна група } \\
(n=48) \\
(M \pm m)\end{array}$ & $\mathrm{CI}$ & $\begin{array}{c}\text { контрольна група } \\
(\mathrm{n}=30) \\
(\mathrm{M} \pm \mathrm{m})\end{array}$ & $\mathrm{CI}$ & \\
\hline Фагоцитарний індекс & $\%$ & $37,50 \pm 1,64$ & 1 & $44,30 \pm 1,17$ & 1 & $<0,05$ \\
\hline НСТ-тест спонтанний & $\%$ & $16,80 \pm 1,01$ & II & $12,50 \pm 0,92$ & I & $<0,05$ \\
\hline НСТ-тест стимульований & $\%$ & $33,70 \pm 2,16$ & 1 & $44,20 \pm 2,75$ & I & $<0,05$ \\
\hline $\begin{array}{l}\text { Показник фагоцитарного } \\
\text { резерву }\end{array}$ & од. & $1,08 \pm 0,26$ & III & $2,53 \pm 0,46$ & I & $<0,05$ \\
\hline $\begin{array}{l}\text { Індекс стимуляції } \\
\text { фагоцитозу }\end{array}$ & $\%$ & $2,01 \pm 0,02$ & III & $3,54 \pm 0,04$ & 1 & $<0,001$ \\
\hline Вміст катіонних білків & од. & $2,40 \pm 0,08$ & 1 & $2,86 \pm 0,04$ & 1 & $<0,01$ \\
\hline Імунологічний коефіцієнт & $\%$ & $26,75 \pm 1,03$ & II & $16,91 \pm 0,87$ & 1 & $<0,01$ \\
\hline 0-лімфоцити & $\%$ & $14,00 \pm 1,37$ & 1 & $15,30 \pm 1,51$ & $\mathrm{I}$ & $>0,05$ \\
\hline Лейко-нульовий індекс & од. & $0,57 \pm 0,15$ & $\mathrm{I}$ & $0,47 \pm 0,13$ & $\mathrm{I}$ & $>0,05$ \\
\hline
\end{tabular}

Примітки: 1. СІП - ступінь імунних порушень; 2. Р - порівняння показників жінок основної групи з показниками контрольної групи

Функціональний стан системи імунітету визначали за показниками лейкограми (табл. 2). Резуль-

тати досліджень засвідчили високу фагоцитарну активність нейтрофілів у жінок контрольної групи.

Таблиця 2. Показники лейкограми у жінок, хворих на туберкульоз легень

\begin{tabular}{|c|c|c|c|c|c|c|}
\hline \multirow[b]{2}{*}{ Показники } & \multirow[b]{2}{*}{$\begin{array}{c}\text { Одиниці } \\
\text { вимірювання }\end{array}$} & \multicolumn{4}{|c|}{ Групи обстежуваних жінок } & \multirow[b]{2}{*}{$\mathrm{P}$} \\
\hline & & $\begin{array}{c}\text { основна група } \\
(n=48) \\
(M \pm m)\end{array}$ & $\mathrm{CI}$ & $\begin{array}{c}\text { контрольна група } \\
(\mathrm{n=30}) \\
(\mathrm{M} \pm \mathrm{m})\end{array}$ & СІП & \\
\hline Лейкоцити & г/л & $7,95 \pm 0,42$ & $\mathrm{I}$ & $7,18 \pm 0,36$ & $\mathrm{I}$ & $>0,05$ \\
\hline Нейтрофільні лейкоцити: & $\%$ & $75,00 \pm 2,31$ & 1 & $67,10 \pm 2,52$ & $\mathrm{I}$ & $<0,05$ \\
\hline - сегментоядерні & $\%$ & $71,60 \pm 2,25$ & $\mathrm{I}$ & $64,60 \pm 2,73$ & $\mathrm{I}$ & $>0,05$ \\
\hline - паличкоядерні & $\%$ & $3,30 \pm 0,18$ & II & $2,40 \pm 0,14$ & $\mathrm{I}$ & $<0,05$ \\
\hline Еозинофіли & $\%$ & $2,06 \pm 0,15$ & II & $0,80 \pm 0,20$ & $\mathrm{I}$ & $<0,01$ \\
\hline \multirow[t]{2}{*}{ Лімфоцити } & $\%$ & $20,31 \pm 2,37$ & $\mathrm{I}$ & $24,30 \pm 2,54$ & $\mathrm{I}$ & $>0,05$ \\
\hline & г/л & $1,42 \pm 0,23$ & II & $2,10 \pm 0,23$ & II & $<0,01$ \\
\hline Моноцити & $\%$ & $6,86 \pm 0,24$ & III & $3,50 \pm 0,40$ & $\mathrm{I}$ & $<0,001$ \\
\hline $\begin{array}{l}\text { Нейтрофільно- } \\
\text { лейкоцитарний коефіцієнт }\end{array}$ & од. & $3,69 \pm 0,13$ & II & $2,76 \pm 0,11$ & $\mathrm{I}$ & $<0,05$ \\
\hline Індекс нейтрофільного зсуву & $\%$ & $32,97 \pm 1,29$ & 1 & $41,33 \pm 1,91$ & $\mathrm{I}$ & $<0,05$ \\
\hline $\begin{array}{l}\text { Лейкоцитарний індекс } \\
\text { інтоксикації }\end{array}$ & од. & $2,57 \pm 0,09$ & $\mathrm{I}$ & $2,35 \pm 0,07$ & $\mathrm{I}$ & $<0,05$ \\
\hline Індекс алергізації & од. & $0,62 \pm 0,05$ & II & $0,46 \pm 0,04$ & $\mathrm{I}$ & $<0,05$ \\
\hline $\begin{array}{l}\text { Індекс неспецифічної } \\
\text { резистентності }\end{array}$ & од. & $28,37 \pm 1,27$ & 1 & $36,21 \pm 1,73$ & $\mathrm{I}$ & $<0,05$ \\
\hline Індекс імунної реактивності & од. & $3,26 \pm 0,13$ & III & $7,17 \pm 0,12$ & II & $<0,001$ \\
\hline ШOE & мм/год & $16,60 \pm 0,18$ & III & $7,20 \pm 0,12$ & $\mathrm{I}$ & $<0,001$ \\
\hline $\begin{array}{l}\text { Співвідношення молодих } \\
\text { форм нейтрофілів }\end{array}$ & од. & $0,05 \pm 0,005$ & 1 & $0,04 \pm 0,01$ & 1 & $>0,05$ \\
\hline
\end{tabular}

Примітки: 1. СІП - ступінь імунних порушень; 2. Р - порівняння показників жінок основної групи з показниками контрольної групи.

У жінок контрольної групи ступінь імунних порушень (І ст.) характеризувався неістотними змінами, а показники клітинної ланки системного імунітету перебували у межах фізіологіч- них величин. Незначні відхилення розглядали як адекватну реакцію системи імунітету на гормональні зміни в динаміці менструального циклу. 
Огляди літератури, оригінальні дослідження, погляд на проблему

Зважаючи, що за умов ТБ в основному формується клітинна імунна відповідь, вивчали показники клітинної ланки системного імунітету.

У пацієнток, які хворіють на ТБ легень, встановлена тенденція до зниження відносної кількості загальних Т-лімфоцитів (CD3+) на 10,7\% (p<0,05), проліферативної здатності на неспецифічний сти- мулятор (ФГА) на $16,5 \%(p<0,05)$ та CD4+ лімфоцитів на 33,4 \% (табл. 3). Зростала відносна кількість CD8+ лімфоцитів на 19,2 \%, проліферативна здатність Т-лімфоцитів на ППД - у 3,19 раза, лейко-Тклітинний індекс зріс на 33,3 \%, що підтверджує дефіцит загальної кількості Т-лімфоцитів та імунологічного коефіцієнта - на 17,4 \%.

Таблиця 3. Показники клітинної ланки імунітету у жінок, хворих на туберкульоз легень

\begin{tabular}{|c|c|c|c|c|c|c|}
\hline \multirow[b]{2}{*}{ Показники } & \multirow[b]{2}{*}{$\begin{array}{c}\text { Одиниці } \\
\text { вимірювання }\end{array}$} & \multicolumn{4}{|c|}{ Жінки досліджуваних груп } & \multirow[b]{2}{*}{$P$} \\
\hline & & $\begin{array}{c}\text { основна група } \\
(n=48) \\
(\mathrm{M} \pm \mathrm{m})\end{array}$ & $\mathrm{CI}$ & $\begin{array}{c}\text { контрольна група } \\
(n=30) \\
(\mathrm{M} \pm \mathrm{m})\end{array}$ & $\mathrm{CI}$ & \\
\hline \begin{tabular}{|l} 
Загальний пул \\
Т-лімфоцитів (CD3+)
\end{tabular} & $\%$ & $62,80 \pm 2,41$ & I & $73,90 \pm 2,89$ & I & $<0,01$ \\
\hline $\begin{array}{l}\text { Субпопуляції Т-лімфоцитів: } \\
-\mathrm{CD}^{4+} \\
-\mathrm{CD}^{8+}\end{array}$ & $\begin{array}{l}\% \\
\%\end{array}$ & $\begin{array}{l}36,40 \pm 1,61 \\
26,30 \pm 1,24\end{array}$ & $\begin{array}{l}1 \\
1\end{array}$ & $\begin{array}{l}46,10 \pm 1,99 \\
21,80 \pm 1,17\end{array}$ & I & $\begin{array}{l}>0,05 \\
>0,05\end{array}$ \\
\hline $\mathrm{IPI}\left(\mathrm{CD}^{4+} / \mathrm{CD}^{8+}\right)$ & од. & $1,38 \pm 0,05$ & II & $2,10 \pm 0,08$ & I & $<0,05$ \\
\hline Лейко-Т-клітинний індекс & од. & $0,13 \pm 0,02$ & $\mathrm{I}$ & $0,10 \pm 0,02$ & 1 & $>0,05$ \\
\hline $\begin{array}{l}\text { РБТЛ: } \\
-3 \text { ФГА } \\
-3 \text { ППД }\end{array}$ & $\begin{array}{l}\% \\
\%\end{array}$ & $\begin{array}{c}51,73 \pm 0,84 \\
3,92 \pm 0,37\end{array}$ & $\begin{array}{l}\text { I } \\
\text { III }\end{array}$ & $\begin{array}{c}61,40 \pm 1,52 \\
1,32 \pm 0,16\end{array}$ & I & $\begin{array}{l}<0,01 \\
<0,01\end{array}$ \\
\hline Імунологічний коефіцієнт & $\%$ & $26,75 \pm 1,03$ & II & $16,91 \pm 0,97$ & 1 & $<0,01$ \\
\hline
\end{tabular}

Примітки: 1. СІП - ступінь імунних порушень; 2. Р - порівняння показників жінок основної групи з показниками контрольної групи.

Зазначені зміни є проявом формування набутого імунодефіцитного стану за клітинним типом, підтвердженням чого $є$ зниження на 62,6 \% імунорегуляторного індексу, що призводить до порушень не лише процесів розпізнавання, але й до автономної саморегуляції у системі імунітету.

ПерерозподілчисельногоспівідношенняТ-хелперів і Т-цитотоксичних лімфоцитів (IPI) призвів до зниження майже удвічі показника $\mathrm{CД}^{4+} / \mathrm{CД}^{8+}$, який наближався до $1(1,34 \pm 0,05)$ у жінок, хворих на ТБ, що свідчить про напружену роботу імунної системи та формування набутого імунодефіцитного стану, що суттєво відображається на ПМЦ.
Дослідження гуморальної ланки імунітету у жінок, хворих на ТБ, виявили суттєві імунні порушення (табл. 4), які встановлені однаково часто серед пацієнток основної групи - по 33,3 \%. Відносна кількість В-лімфоцитів (CD ${ }^{20+}$ клітин) зростала на $46,5 \%$, проте загальна функціональна здатність знижувалася на 5,6\%.

Негативним виявилося зниження рівня IgG, який виконує основну захисну роль у протиінфекційному захисті - на 33,2 \%, також зростала концентрація IgM - на 53,8 \% та IgA - на 81,4\%.

Таким чином, вперше виявлений ТБ легень у жінок репродуктивного віку $\epsilon$ вагомим чинником

Таблиця 4. Показники гуморальної ланки імунітету у жінок, які хворіють на туберкульоз легень

\begin{tabular}{|c|c|c|c|c|c|c|}
\hline \multirow[b]{2}{*}{ Показники } & \multirow{2}{*}{$\begin{array}{c}\text { Одиниці } \\
\text { вимірювання }\end{array}$} & \multicolumn{2}{|c|}{$\begin{array}{c}\text { Основна група } \\
(n=48)\end{array}$} & \multicolumn{2}{|c|}{$\begin{array}{c}\text { Контрольна група } \\
(n=30)\end{array}$} & \multirow[b]{2}{*}{$P$} \\
\hline & & $\begin{array}{c}\text { пацієнтки, хворі на } \\
\text { туберкульоз легень } \\
(\mathrm{M} \pm \mathrm{m})\end{array}$ & $\mathrm{CI}$ & $\begin{array}{c}\text { здорові жінки } \\
(n=32) \\
(M \pm m)\end{array}$ & $\mathrm{CI}$ & \\
\hline В-лімфоцити $\left(\mathrm{CD}^{20+}\right)$ & $\%$ & $18,52 \pm 1,23$ & II & $12,64 \pm 1,17$ & $I$ & $<0,01$ \\
\hline $\begin{array}{l}\text { Лейко-В-клітинний } \\
\text { індекс }\end{array}$ & од. & $0,42 \pm 0,05$ & 1 & $0,53 \pm 0,05$ & 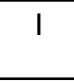 & $<0,05$ \\
\hline $\begin{array}{l}\text { Концентрація } \\
\text { імуноглобулінів }\end{array}$ & г/л & $15,44 \pm 0,37$ & $I$ & $16,31 \pm 0,46$ & $I$ & $<0,05$ \\
\hline $\lg M$ & г/л & $2,77 \pm 0,18$ & III & $1,32 \pm 0,17$ & II & $<0,05$ \\
\hline $\lg G$ & г/л & $10,13 \pm 0,63$ & II & $13,50 \pm 0,88$ & 1 & $<0,05$ \\
\hline $\lg A$ & г/л & $2,54 \pm 029$ & III & $1,49 \pm 0,34$ & 1 & $<0,05$ \\
\hline
\end{tabular}

Примітки: 1. СІП - ступінь імунних порушень; 2. Р - порівняння показників жінок основної групи з показниками здорових жінок. 
Огляди літератури, оригінальні дослідження, погляд на проблему

порушень системного імунітету, на тлі якого виникають ПМЦ.

Зниження імунної реактивності організму та детоксикаційної функції печінки, застосування протитуберкульозних препаратів, інтоксикація, яка має місце у кожної пацієнтки, хворої на ТБ легень, вимагає проведення імунокорекції з урахуванням вищезазначених показників.

Висновки. 1. Порушення менструального циклу у пацієнток, хворих на туберкульоз легень, відбуваються на тлі імунодефіцитного стану за клітинним типом зі зниженням відносної кількості Т-лімфоцитів, зростанням супресорного компонента імунної відповіді.

2. Комплексне лікування порушень менструального циклу у жінок, хворих на туберкульоз легень, доцільно проводити із застосуванням імунокоректорів під контролем імунограми.

Перспективи подальших досліджень. Наступні дослідження передбачають вивчення показників цитокінів при порушенні меструального циклу у жінок, які хворіють на туберкульоз легень.

\section{ЛІТЕРАТУРА}

1. К вопросу о патологии иммунитета при туберкулезе легких / В. В. Новицкий, О. В. Воронкова, О. И. Уразова [и др.] // Патолог. физиология и эксперимент. терапия. - 2008. - № 1. - С. 15-18.

2. Клічук Р. В. Порушення репродуктивного здоров'я у жінок, хворих на туберкульоз легень / Р. В. Клічук, С. П. Польова, А. М. Біньковська // Клінічна та експерименальна патологія. - 2011. - Т. Х, № 4 (38). - С. 46-48.

3. Клічук Р. В. Ультразвукова діагностика порушень фертильності у жінок, хворих на туберкульоз легень / Р. В. Клічук, С. П. Польова, Т. О. Коцур // ПАГ. - 2012. № 2 (450). - С. 92-94.

4. Клічук Р. В. Чинники ризику розвитку туберкульозу у жінок репродуктивного віку / Р. В. Клічук, С. П. Польова // Одеський медичний журнал. - 2012. № 1 (129). - С. 38-40.

5. Тодоріко Л. Д. Сучасні аспекти перебігу туберкульозу легень у жінок / Л. Д. Тодоріко // Клінічна іму-

нологія. Алергологія. Інфектологія. - 2014. - № 3 (72). С. 56-61.

6. Токарева Л. А. Туберкулез и его влияние на репродуктивное здоровье / Л. А. Токарева // Акушерство и гинекол. - 2009. - № 4. - С. 34-36.

7. Трифонова Н. Ю. Социальные аспекты туберкулеза у женщин / Н. Ю. Трифонова, Н.В.Полунина // Проблемы туберкулеза и болезней легких. - 2007. № 1. - С. 3-5.

8. Федун 3. В. Туберкулез половых органов женщин / З. В. Федун, В. Г. Калашникова, Е. П. Гнатко // Новости медицины и фармации в Украине. - 2004. № 18 (158). - С. 20.

9. Фещенко Ю. І. Організація контролю за хіміорезистентним туберкульозом в Україні / Ю. І. Фещенко, В. М. Мельник. - К. : Здоров'я, 2013. - 703 с.

10. Чернушенко К. Ф. Імунологічні методи у діагностиці туберкульозу / К. Ф. Чернушенко // Лабораторна діагностика. - 2005. - № 2 (32). - С. 61-66.

\section{IMMUNE HOMEOSTASIS UNDER MENSTRUAL CYCLE DISORDERS IN WOMEN SUFFERING FROM TUBERCULOSIS}

\section{Kovel Medical College}

๑O. V. Romaniuk, S. P. Polyova

SUMMARY. The research findings of immune resistance parameters in patients with menstrual irregularities, suffering from tuberculosis are presented. It is shown that the menstrual cycle in this cohort of women undergoes significant changes as a result of violations of non-specific effector immune defense system and immune system cell level. It is found that patients with pulmonary TB, acquired immunodeficiency state is formed by the cell type, which provides regulation of phagocytosis and lysis of Mycobacterium tuberculosis and form the anti-tuberculosis immunity. It is shown that the menstrual cycle (MC) in a cohort of women undergoes significant violations by reducing the functional ability of B-lymphocytes ( $\mathrm{CD}^{20+}$ ) by $46.5 \%$, despite a compensatory increase in their relative amount, functional capacity and reduction of production of major classes of immunoglobulins by $5.6 \%$. In women with tuberculosis, immune disorders of humoral immune system link manifest by I, II, and III grades depending on the degree of spread of tuberculosis. According to results of determining immuno-hormonal homeostasis it is established the trend of menstrual dysfunction in women, depending on the form of tuberculosis injury. Patients suffering from disseminated tuberculosis, prone to hiperpolymenorhoea against a background of absolute and relative estrogenia with MC lutein phase and complicated par. In women suffering from fibro-cavernous tuberculosis, MC violations occur in forms of algodysmenorrhea, often occur anovulatory cycles determined by the absolute or relative estrogenia and MC lutein phase deficit. Focal pulmonary tuberculosis with no signs of intoxication does not contribute to the violation of MC in women. These patients usually present lutein phase deficit, relative estrogenia.

KEY WORDS: tuberculosis, menstrual cycle, immune system, humoral immunity, diagnostics. 